\title{
THE VIEWPOINTS OF INDONESIAN ISLAMIC SCHOLARS ON THE FATWA CONCERNING TERRORISM ISSUED BY THE INDONESIAN ULEMA COUNCIL (MUI): AN ANALYSIS
}

\author{
Hudzaifah Achmad Qotadah* \\ Noor Naemah Ab Rahman**
}

\begin{abstract}
Terrorism is a form of violation of human rights and civilization hence it is-an extremely dangerous threat to a country's sovereignty. The incidence of several terrorist attacks in certain countries, including Indonesia, triggers turmoil and fear on several organizations, including the Religious Indonesian Ulema Council (MUI). The MUI is an organization representative of Indonesia's ulema and Islamic religious scholars. These acts of terrorism resulted in the Indonesian Ulema Council, through the fatwa commission at the national ijtima of ulema, to enforce a fatwa on terrorism referred to as Fatwa No.03 Year 2004. Regrettably, numerous terrorist attacks are still being conducted in Indonesia, despite the issuance
\end{abstract}

* Master Candidate, Department of Fiqh and Usul, Academy of Islamic Studies, University of Malaya, 50603, Kuala Lumpur. hudzaifahachmad47@gmail.com

** Associate Professor, Department of Fiqh and Usul, Academy of Islamic Studies, University of Malaya, 50603, Kuala Lumpur. naemah@um.edu.my 
of the fatwa on terrorism by the MUI. Regrettably, various terrorist attacks are still taking place in the country. This fatwa failed to provide a sustainable solution to issues of terrorism in Indonesia. This could be due to the fact that it is not widely disseminated to the Indonesian community, religious as well as other organizations, thus leading to ignorance of the fatwa concerning terrorism among individuals and groups. Hence, the primary objective of this research is to analyze Indonesian Islamic scholars' insights on the MUI fatwa on terrorism. The research employed a full qualitative method and data documentation through the interview method, which was then analyzed descriptively. Solo, a region reported as one of the red zones of radicalism and terrorism in Indonesia was chosen as the research location.

Keywords: fatwa, scholars, MUI, terrorism

\section{INTRODUCTION}

The fatwa is. comparably the most flexible laws product, since it is a response or answer to a particular question sought by a fatwa requester or mustafti. ${ }^{1}$ The fatwa plays a fundamental position in the development of Shariah or Islamic jurisprudence as a fatwa is the point of view presented by Islamic scholars or Fuqaha on the legal standing of some differing matters that arose within societies.

Furthermore, whenever a new issue that has not yet been explicitly addressed by the Qur'an, hadith, ijm $\bar{a}$, or the earlier fuqaha, the fatwa should be applied, as it is one of the most capable authoritative rulings to respond to or decide on the legal standing of the question. ${ }^{2}$

1 Isa Ansori, "Kedudukan Fatwa di Beberapa Negara Muslim (Malaysia, Brunei Darussalam dan Mesir)," Analisis: Jurnal Studi Keislaman, vol. 17, no. 1 (2017), 138-139.

2 M. Erfan Riadi, "Kedudukan Fatwa ditinjau dari Hukum Islam dan Hukum Positif: Analisis Yuridis Normatif," Ulumuddin: Journal of Islamic Legal Studies, vol. 6, no. 4 (2010), 471-472. 
There are three approaches in establishing a fatwa, the traditional-conservative, ultra-rational or literal judgements. Therefore, a fatwa that uses the wasatiyah approach is capable of becoming counter-ideology against fields which contradict actual Islamic principles, so a fatwa based on that approach could be the answer to the problem of promoting peaceful living in societies. ${ }^{3}$

Through fatwas, Islamic principles can be implemented by pursuing the principles of Shariah and theological definitions that have been contradictory within the true beliefs and practices can be changed. The fatwa also has the function of maintaining the purity and holiness of Islamic principles as that would ensure consistency to the entire norms of Islamic law. Hence, Darul Ifta, Majma al-Buhuth al-Islamiyah, or other such organisations which carry out the same functions for almost every Islamic nation, have been assigned to safeguard the primary interests of the Muslim world. ${ }^{4}$ For instance, in Indonesia it is the Indonesian Ulema Council (MUI).

The establishment of a fatwa organisation has become a symbol among Muslims worldwide including Indonesia. The Indonesian Ulema Council, for instance, does have many functionalities; one of which is issuing fatwas regarding new problems relating to Islamic laws or syarak rulings. This obviously shows that fatwa organizations hold an essential position in the way of life of Muslims and Indonesia is no exception. ${ }^{5}$

According to the Indonesian Government Intelligence Department, there were three factors that might have generated acts of terrorism in Indonesia. Those three factors were based on the mistaken understanding of religious dogmas, e.g (1) Certain individuals were mistaken about understanding jihad because,

3 Mohd Anuar Ramli \& Rahimin Affandi Abdul Rahim, "Fatwa Sebagai Medium Counter-Terrorisme: Rethinking Eksistensi Fatwa dalam Menangani Terorisme," Al-Banjari: Jurnal Ilmiah Ilmu-Ilmu Keislaman, vol. 17, no. 2 (2018), 223-225.

4 Zulkifli Mohamad, "Institusi Mufti dan Fatwa: Satu Analisa Terhadap Enakmen dan Beberapa Fatwa Pilihan Negeri Sembilan," (Ph.D Thesis, Universiti Sains Malaysia, Pulau Pinang, 2004).

5 Slamet Suhartono, "Eksistensi Fatwa Majelis Ulama Indonesia dalam Perspektif Negara Hukum Pancasila," Al-Ihkam: Jurnal Hukum dan Pranata Sosial, vol. 12, no. 2 (2017), 449-450. 
among terrorists, jihad will only be applied in the form of qital (war) (2) Their understanding of the meaning of takfir seems misleading, they believe that somebody with different views with them could be murdered even if he is Muslim. (3) They widened the definition of thaghut, for example, if government employees or federal ministers produce any policy which is not grounded upon Islamic Shariah law, they may consider it as thaghut and therefore feel obligated to fight them. ${ }^{6}$

There are ample acts of terror amongst Muslim nations, as well as for Indonesia, which are driven by religious beliefs. These create a media narrative where Islam appears to be identical to violence ${ }^{7}$ and allow them to endorse the path of violence to strengthen their religion and this happened in Indonesia where the terrorist perpetrator in Indonesia is often a Muslim ${ }^{8}$ even though it diverges from authentic Teachings of Islam. ${ }^{9}$

The act of terrorism influenced by religious views in Indonesia is quite worrying to many of its citizens. Terrorism threatens a country's independence and sovereignty. For that reason, the Indonesia Ulema Council (MUI) declared the fatwa about terrorism, namely the Fatwa No. 03 the Year 2004 concerning Terrorism. ${ }^{10}$ This fatwa was expected to offer Muslims in Indonesia good understanding as well as clarification regarding the meaning of jihad, the concept of jihad by Islamic law principles, the differences between terrorism, extremism, radicalism, suicide bombing and amaliyah al-istisyhadiyah, etc. To conclude, all

6 https:/www.radarcirebon.com/3-hal-biang-keladi-terorisme-inikata-bin.html, accessed on 25 March 2019.

7 Junaidi Abdillah, "Radikalisme Agama: Dekontruksi Tafsir AyatAyat Kekerasan dalam Al-Quran," Journal: Kalam, vol. 8, no. 2 (2014), 281.

8 Abu Rokhmad, "Radikalisme Islam dan Upaya Deradikalisasi Paham Radikal," Walisongo: Jurnal Penelitian Sosial Keagamaan, vol. 20, no. 1 (2012), 80.

$9 \quad$ Muhd Imran Abd Razak \& Rahimin Affandi Abdul Rahim, "Analisis Fahaman Ekstremis Agama dan Media Sosial di Malaysia," Asian Journal of Environment, History and Heritage, vol. 2, no. 1 (2018), 94.

10 KH. Ma'ruf Amin, Pengantar dalam Himpunan Fatwa MUI 2003 (Jakarta: MUI Pusat, 2003), vi. 
acts of terrorism in Indonesia, whether it was driven by religious belief or otherwise, will indeed be considered as dangerous threats towards Indonesia's independence and sovereignty. ${ }^{11}$

\section{RESEARCH METHOD}

In this research, the full qualitative method was used and supporting documents data relevant to the topic of this research, was then analyzed descriptively. Two research instruments, the library research and interview method were used with interviews being conducted with various Muslim scholars across various religious entities in Solo or Surakarta. In order to conduct these interviews, the researcher picked Solo or Surakarta as the research location mainly for the reason that Solo is classified as one of Indonesia's red zone regions for the spread of radicalism and terrorism. ${ }^{12}$

The interview involved 9 Islamic scholars located in Surakarta, with each person serving either as the chairman or vice-chairman, or as representatives of the different Islamic organizations in Surakarta. Each organization has its own stream of followers. What follows are the names of the interviewees:

a) Ustad Sirajuddin and Ustad Azhar Nurachman as Chairman and representative of Dewan Pimpinan Daerah (DPD) of Wahdah Islamiyah (WI) Surakarta. The interview was conducted on Tuesday, 26 November 2019, 07:30 p.m. at the Yayasan Al Quds Office, Surakarta.

b) Ustad Shobbarin Syakur, as Secretary General and representative of Majelis Mujahidin Indonesia (MMI). The interview was conducted on Tuesday, 27 November 2019, 02:00 p.m. at the respondent's home in Surakarta.

c) Dr. M. Abdul Fattah Santoso, M,Ag as Vice Chancellor IV of

11 Golda Eska, "Terorisme Ancaman Nyata yang Memengaruhi Keutuhan Bangsa," https://mediaindonesia.com/read/detail/211901terorisme-ancaman-nyata-yang-memengaruhi-keutuhan-bangsa, accessed on 25 March 2019.

12 https://www.jawapos.com/jpg-today/10/09/2018/rawan-pahamradikal-solo-masuk-zona-merah-terorisme/, accessed on 22 April 2019. 
UMS and representative of Pimpinan Wilayah Muhammadiyah (PWM) Jawa Tengah. The interview was conducted on Friday, 29 November 2019, 12:30 p.m. at the Muhammadiyah University of Surakarta (UMS).

d) Prof. Dr. Muhammad Da'i, M.Si, Apt as Vice Chancellor 1 of Muhammadiyah University of Surakarta (UMS) and representative of Ikatan Cendekiawan Muslim Indonesia (ICMI) Solo . The interview was conducted on Friday, 29 November 2019, 03:30 p.m. at the Muhammadiyah University of Surakarta (UMS).

e) Ustad Syamsul Bahri as Chairman and representative of Dewan Pimpinan Daerah (DPD) Lembaga Dakwah Islam Indonesia (LDII) Kota Surakarta . The interview was conducted at Saturday, 30 November 2019, 07:00 a.m. at the respondent's home in Surakarta.

f) KH. Muhammad Dian Nafi as Caretaker of Pesantren AlMuayyad Windan and representative of Nahdlatul Ulama Surakarta. The interview was conducted on Friday, 06 December 2019, 07:00 a.m. in Pesantren Al-Muayyad Windan, Surakarta.

g) Ahmad Sukidi, S.Ag, M.Pd as Chairman of Majelis Pendidikan Kader and representative of Pimpinan Daerah Muhammadiyah (PDM) Surakarta. The interview was conducted on Thursday, 12 December 2019, 09:00 a.m. in the Secretariat Office of Pimpinan Daerah Muhammadiyah (PDM) Surakarta.

h) Dr. Mu'inudinillah Basri, MA as Chairman and representative of Dewan Syariah Kota Surakarta (DSKS). The interview was conducted on Monday, 15 December 2019, 08:00 a.m. in the ISKA Mosque, Surakarta.

\section{THE ESSENCE OF TERRORISM}

Linguistically, terrorism originated from terrere, a Latin word that means causing one to tremble by creating someone to feel 
frightened. ${ }^{13}$ According to the Indonesian Dictionary, terror is an act committed by either an individual or group to spread fear and violence. A terrorist is described as someone who uses violence to trigger fear and terror. Indeed, terrorism is a calculated method of using violence which in turn produces chaos, in order to accomplish certain agendas, mainly political ones. ${ }^{14}$

The Black Law Dictionary defines terrorism as: "The use of any threat of violence to intimidate and create worry, notably as a method for manipulating political behaviours." 15

The 1937 UN Convention determines terrorism as any form of violence specifically demonstrated towards any country, producing some kind of terror for certain persons, groups or general audiences. ${ }^{16}$

Therefore, it can be concluded that terrorism is as an act of terror designed to create fear or apprehension for someone else, either executed by individuals or groups, as well as to accomplish some particular outcomes.

There are three phases of terrorism in the motivational concept of terrorism: First, eliminating the correlation between a target of terror as well as motive to terror. Second, citizens are in the comfort of enjoying their daily routines due to the nation's security but terrorism destroys this confidence, bringing mistrust on the government regarding safeguarding and protecting its people. Third, due to the chaos, terrorism shifts as well as affects people to pursue the same violence through vengeance. So, the general nature of terrorism is endorsing violence as well as using violent threats to gain specific goals. ${ }^{17}$

13 Abdul Muis Naharong, "Terorisme Atas Nama Agama," Journal of Refleksi, vol. 13, no. 5 (2013), 596.

14 Departemen Pendidikan Nasional, Kamus Bahasa Indonesia (Jakarta: Pusat Bahasa, 2008), 1511.

15 Usman, "Model Diradikalisasi Narapidana Terorisme Studi Perbandingan Diradikalasi di Yaman, Arab Saudi, Singapura, Mesir dan Indonesia," Inovatif: Jurnal Ilmu Hukum, vol. 7, no. 2 (2014), 3.

16 Ibid., 4.

17 Chaider S. Bamualim \& Ridwan al-Makassary, "Nexus Antara Fundamentalisme Islam dan Terorisme," Millah: Jurnal Studi Agama, vol. 5, no. 1 (2006), 36. 
Besides, there are two characteristics of terrorism as stated by Zulfi Mubarak: First, direct terrorism, that is a terrorist aiming to commit direct terrorist acts over its prime targets, like those of selected people within authority as well as specific positions: the president, prime minister, king, queen, etc. Second, indirect terrorism, which is also an act of terrorism that attempts to threaten its non-target indirectly. This may be a bombing of government facilities, bank robbery, kidnapping a powerful person, etc. This is designed to weaken the credibility of a government towards offering protection for its own people. ${ }^{18}$

However, the acts of terrorism committed in Indonesia are triggered not just by theological demands but also through the economies such as deprivation, ${ }^{19}$ social, ${ }^{20}$ level of education, demographic, cultural, psychological factors, inequality, political factors $^{21}$ such as the emergence of various radical groups for instance Front Pembela Islam (FPI), ${ }^{22}$ Jamaah Islamiyah (JI) that are still closely linked to Darul Islam (DI) ${ }^{23}$ and Jamaah Ansharut Daulah (JAD), etc. ${ }^{24}$ Therefore, terrorism can also be caused by government discrimination against such a particular group. This discrimination might be in the form of unwillingness to accommodate to the group's aspirations as well as willingness, and

18 Zulfi Mubarak, "Fenomena Terorisme di Indonesia: Kajian Aspek Teologi, Ideologi dan Gerakan," Salam: Jurnal Studi Masyarakat Islam, vol. 15, no. 2 (2012), 245.

19 August Corneles Tamawiy, "Bom Surabaya 2018: Terorisme dan Kekerasan Atas Nama Agama," Gema Teologika: Jurnal Teologi Kontekstual \& Filsafat Keilahian, vol. 4, no. 2 (2019), 178.

20 Michael Seno Rahardanto, "Mengkaji Sejumlah Kemungkinan Penyebab Tindak Terorisme: Kajian Sosio-Klinis," Experientia: Jurnal Psikologi Indonesia, vol. 1, no. 1 (2012), 73.

21 Fatkhuri, Faktor Pendukung Terbentuknya Radikalisme dan Terorisme di Indonesia (Jakarta: Universitas Pembangunan Nasional Veteran, 2012), 17-18.

22 Ibid., 19 .

23 Tiara Firdaus Jafar, Arfin Sudirman \& Affabile Rifawan, "Ketahanan Nasional Menghadapi Ancaman Lone Wolf Terrorism di Jawa Barat," Journal Ketahanan Nasional, vol. 25, no. 1 (2019), 81-82.

24 Ibid., 9-10. 
it can be created through some anarchist acts that could contribute to terrorism..$^{25}$

Islam is known as the religion of rahmatan lil alamin, which spreads a message of peace, love and harmony to the world. Hence, violence in any form including terrorism activities is strictly forbidden in Islam. The al-Qur'an prohibits the believers from insulting other religions, especially through acts of terrorism. It says:

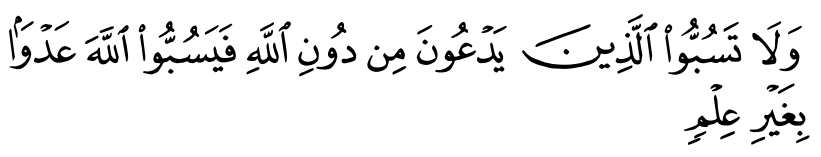

"And do not insult those they invoke other than Allah, lest they insult Allah in enmity without knowledge. Thus We have made pleasing to every community their deeds. Then to their Lord is their return, and He will inform them about what they used to do."

(Surah al-An‘ām, 6: 108)

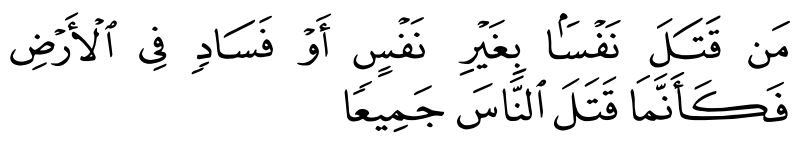

"Whoever kills a soul unless for a soul or for corruption [done] in the land - it is as if he had slain mankind entirely."

(Surah al-Mā’idah, 5: 32)

Also in a hadith:

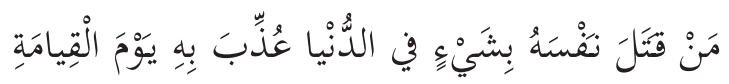

"Whoever kills himself with something, he will be

25 Ahmad Rais Karnawan, "Latar Belakang Terorisme dilihat dari Perspektif Sosio-Historis," 11, https://www.academia.edu/38460413/ latar_belakang_terorisme_dilihat_dari_perspektif_sosio-historis., accessed on 22 October 2019. 
punished with it in the Hereafter." 26

Therefore, based on the verses of the al-Qur'an and hadith, it is clearly shown that Islam strictly forbids Muslims to undertake any type of terrorist activity.

\section{THE ESSENCE OF THE FATWA}

The fatwa means recommendations and answers to the questions. This also means a compilation of Islamic decisions presented by the mufti or ulama in response to a question by a musftafti. ${ }^{27}$ Terminologically, Yūsuf al-Qaraḍāwī identifies a fatwa as:

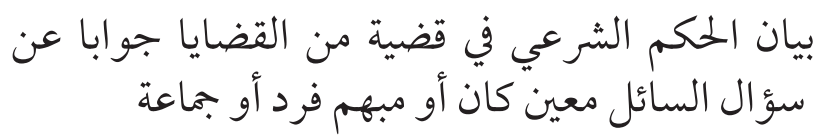

"Explaining Shariah law to a problem or question across different problems as well as providing answers to a questioner's question (mustafti), whether explicitly or collectively, individually or jama'ah (group))." 28

The term fatwa can be identified repeatedly throughout multiple verses in the al-Qur'an by using the term or sighat yas'alunaka and yastaftunaka (يسئلونك) for instance:

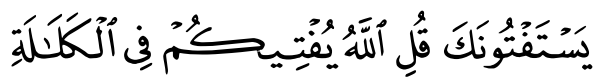

"They request from you a [legal] ruling. Say, "Allah gives you a ruling concerning one having neither descendants nor ascendants (as heirs)."

(Surah al-Nisā', 4: 176)

26 Muslim, Abī al-Husayn Muslim Ibn al-Hajjāj Ibn al-Qushayrī alNaysabūrī, Sahị̣̄ Muslim (Bayrūt: Dār al-Fikr, 2003), 74, "Kitāb alİmān," no. hadis 110.

27 Kamus Bahasa Indonesia, Departemen Pendidikan Nasional (Jakarta: Pusat Bahasa, 2008), 406.

28 Yūsuf al-Qaraḍāwī, al-Fatwā bayna al-Indibāt wa al-Tasayyub (Qāhirah: Dār al-Ṣahwah li al-Nashr, 1988), 11. 


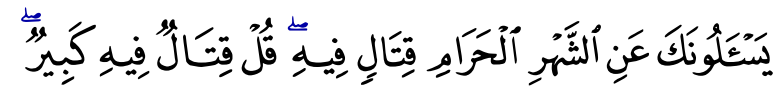

"They ask you about the sacred month - about fighting therein. Say, "Fighting therein is great sin."

(Surah al-Baqarah, 2: 217)

Therefore, the legal framework of the fatwa may differ across different scenarios. First, it becomes Fardu Ain if a country has only one mufti, in this situation a mufti is obligated to issue a fatwa whenever requested. ${ }^{29}$ Second, it becomes Fardu Kifayah, if a country has several muftis. ${ }^{30}$ Third, it becomes Makruh, an act to issue a fatwa will be makruh once the mufti has been in less ideal physical health, in unstable emotions like feeling frustrated, ill, hunger, sleepy, or facing a huge problem, etc. ${ }^{31}$ Fourth, it becomes Haram when the fatwa is issued by people who do not understand ${ }^{32}$ and do not fully comprehend the correct answer to the question. ${ }^{33}$

Next, the category of fatwa as seen through the worldview is classified into two sections. First, the collective fatwa (al fatwa ijma'i) which is the type of fatwa formed and issued by a group or organization technically competent and authorised to release fatwa like Majma al-Buhuth al-Islamiyah, Majma al-Fiqh al-Islami and Majelis Ulama Indonesia, Majelis Tarjih Muhammadiyah, Lembaga Bahsu Al Masail, etc. ${ }^{34}$ Second, the personal fatwa (al fatwa al fardi) which is the type of fatwa based on research and investigation conducted by a person, such as fatwa related to fiqh

29 Aḥmad bin Hamdan al-Ḥarranī al-Hanbalī, Șifāt al-Fatwā wa alMuftī wa al-Mustaftī (Dimashq: al-Maktabah al-Islāmī, 1380H), 6.

30 Ibid, 6

31 Ibid,. 77

32 'Abd Allāh bin Muhammad bin Sa'ad, al-Fatwā fì al-Sharī'ah alIslāmiyah (Riyāḍ: Maktabah Obeikan, 2008), 60-61.

33 Muḥammad Jalāl al-Dīn al-Qāṣimī, al-Fatwā fì al-Islām, ed. Muḥammad 'Abd al-Ḥakīm al-Qāḍ̄i (Bayrūt: Dār al-Kutub al'Ilmiyyah, 1986), 76.

34 Ibid,. 16. 
madhahib, the fatwa of Yusuf al-Qaradawi, fatwa Ibn Taimiyah, etc. ${ }^{35}$

Islamic law which is fatwa at different periods, places and circumstances, has experienced several changes from one era through to another, which in itself is a necessary condition to all Muslims, as well as for Indonesian Muslims in order to maintain their sustainability of living. The fatwa is also known as a medium in knowing the status and regulations based on the maqasid of Allah SWT to His ummah. Further, the fatwa can be an effective approach in distributing knowledge and information to the ummah. ${ }^{36}$ Thus, by being reminded of the significance of the fatwa and the functions, the ummah should never ever neglect fatwas given by muftis since the fatwa is delivered for the benefit of the ummah and any fatwa produced by the ulema should always be pursued since the ulema have been shown to be the heirs of the prophets, ${ }^{37}$ as pronounced by Prophet Muhammad SAW: "Indeed the Ulema is the heir of the Prophets." 38

Imam al-Nawawi mentioned in his book:

"The duty of giving the fatwa is indeed a huge risk, prestige and honour because the Mufti is considered to become the heirs of the prophets and fulfills the obligations of fardu kifayah, but is always vulnerable to mistakes. The scholars said: Mufti is a person who signed Allah SWT's affairs. " ${ }^{39}$

35 Heri Fadli Wahyudi \& Fajar, "Metode Ijtihad Komisi Fatwa Majelis Ulama Indonesia dan Aplikasinya dalam Fatwa," Cakrawala: Jurnal Studi Islam, vol. 13, no. 2 (2018), 124.

36 Rusli, "Tipologi Fatwa di Era Modern dari Offline ke Online," Hunafa: Jurnal Studia Islamika, vol. 8, no. 2 (2011), 273.

37 Ahmad Mukhlishin, Aan Suhendri, Muhammad Dimyati, "Metode Penetapan Hukum dalam Berfatwa," Al-Istinbath: Jurnal Hukum Islam, vol. 3, no. 2 (2018), 168-169.

38 Abī Dāwud, Sulayman Ibn al-Ash'ath al-Sijistānī al-'Azdī, Sunan $A b \bar{l} D \bar{a} w \bar{u} d$, vol. 5, ed. 'Abd al-Lațîf Hirz Allāh (Dimashq: Dār al-Risālah al-'Alamiyyah, 2009), "Kitāb al-'Ilm, Bāb al-Ḥats 'ala Thalab al-'Ilm," hadis no. 3641, 485.

39 Al-Nawawī, Abī Zakariyyā Maḥy al-Dīn Ibn Sharf, al-Majmū ‘ Shar Zakariyyā Mahy, vol. 1 (Jeddah: Maktabah al-Irshād, 1999), 72. 


\section{THE POSITION OF FATWA IN SHARIAH LAW AND POSITIVE LAW IN INDONESIA}

The fatwa has a significant position in Islam as it is "a description of Sharia law on an issue or problem or response to a mustafti question, either individually or collectively." According to views of the ulema, a fatwa is optional or iktihariyah, and is designed to become a legally unbinding solution to the mustafti (a person requesting a fatwa). ${ }^{40}$ Fatwas other than any fatwa requested by a mustafi becomes i'laniyah or informational, indicating it to be more than a discourse, whether that particular fatwa or whether a proposed fatwa from another mufti is being considered. ${ }^{41}$

The position of the fatwa in the Indonesian constitution is non-binding as it is categorized as matter of a legal argument. According to Yusril, a fatwa is generally issued in order to provide clear meaning among individuals who feel unclear about a certain topic or subject from the perspective of Islamic law. Islamic law, however, is still not ius constituutum (the current law or constructive law) as well as not ius constituendum (a law that has been dreamed of or strived for in the future), so fatwa will not be a jurisdiction in Indonesia which binds, must always be implemented or established by all Indonesian Muslims. ${ }^{42}$

That position as regulated based on the Law Of The Republic of Indonesia No. 12 Of 2011 concerning making rules on article 7 mentions that the types and hierarchy of rules consists of: (1) Constitution of the Republic of Indonesia of 1945; (2) People's Consultative Council Decree; (3) Law or Government Regulation In Lieu of Law; (4) Government Regulation; (5) Presidential

40 Kementerian Wakaf Kuwait, al-Mawsū'ah al-Fiqhiyyah alKuwaytiyyah, vol. 32 (Mișr: Mathabi‘ Dār al-Șafwah, 1988), 49.

41 M. Erfan Riadi, "Kedudukan Fatwa ditinjau dari Hukum Islam dan Hukum Positif: Analisis Yuridis Normatif," 475-476.

42 Yusril Ihza Mahendra, "Hukum Islam Adalah The Living Law", Republika.co.id, https://www.republika.co.id/berita/nasional/hukum /16/12/24/oiope6301-yusril-hukum-islam-adalah-the-living-law, accessed on 12 December 2019. 
Regulation; (6) Province Regulation; and (7) Regency or Municipality Regulation. ${ }^{43}$

Although the fatwa is ikhtiyari it should be binding to all Muslims indirectly, as said by several respondents:

"Fatwa is not binding legally but spiritually, but if fatwa is haq (right), people should feel bound by fatwa." (Mu'inudinillah Basri, Chairman DSKS)

"... Fatwa is an option, and fatwa will not have power or authority, "but binding sacredly ..." (Muhammad Da'i, Vice-Chancellor I of UMS and Chairman of ICMI Solo)

"Fatwa is a guideline, and guideline is ikhtiari, so it cannot be forced upon, and MUI is not a government agency... because our country is based on Pancasila, we cannot force a fatwa... but it should exist as an option or alternative..." (Abdul Fattah Santoso, Vice Chairman of PWM Jawa Tengah)

From the viewpoint of the researcher, the binding of the fatwa depends significantly on the condition of a mustafti and the problem at a specific moment. If it is extremely critically necessary and also has a huge maslahah for peoples or nations such as the MUI fatwa concerning terrorism, then the fatwa should really be authoritative to eliminate fatwas which have a different viewpoint as said by several respondents:

"Fatwa of MUI should be binding because it (comes) from the Council but fatwa issued by an ulema is not binding. Fatwa issued by an organization should be binding" (Sirajuddin, Chairman of DPD Wahdah Islamiyah WI Surakarta)

"Terrorism currently is a (beautiful) issue to be exploited, and it needs to be taken seriously. Fatwa of MUI should be considered by the law enforcement agency." (Azhar Nurachman, Chairman of Depart-

43 Slamet Suhartono, "Eksistensi Fatwa Majelis Ulama Indonesia dalam Perspektif Negara Hukum Pancasila," 458. 


\section{ment Dakwah \& Candidate of DPD WI)}

"Fatwa, even though not binding legally in Indonesia, should be binding for every Muslim, because MUI fatwa is created by our ulema. Still, the fatwa is essentially an option, may and may not be implemented. However, if the fatwa is very important, it should receive support from the government or other organizations." (KH. Muhammad Dian Nafi, Caretaker Pesantren Al-Muayyad Windan Surakarta)

Therefore, when a fatwa is not just a legal opinion but is also binding and mandatory, it could be better in this interpretation and some of the above respondents have endorsed this viewpoint. If the MUI fatwa concerning terrorism is no longer merely a legal opinion, the fatwa is expected to have a positive legal force, which will erase misconceptions in understanding jihad and steer people away from other fatwas with different opinions, especially in understanding amaliyah istisyhadiyah. In addition, this fatwa is also expected to be more socialized to the government, religious organizations and related institutions through mass media and other mediums. As a result, this fatwa will reach every level of the population, from the lower class to the medium and higher classes.

Could the MUI fatwa, however, be binding and not just a legal opinion? The answer is that it could, if modified into a positive law, such as a fatwa for the sharia economics issued by Dewan Syariah Nasional (DSN) MUI. Even so, it is due to a series of requirements to be fulfilled before trying to formulate regulations to become a positive law. For instance, (1) must be in the form of writing, (2) containing legal norms throughout the type of orders, regulation, authorisation, etc., (3) broadly binding (4) created or issued by an authorized institution which guaranteed by the 1945 State Constitutions of the Republic of Indonesia or laws, and (5) formed through procedures regulated in legislations. ${ }^{44}$

$44 \quad$ Ibid., 455. 


\section{FATWA ISSUED BY INDONESIAN ULEMA COUNCIL REGARDING TERRORISM}

In the regional and national context, the phenomenon of terrorism especially motivated by theological matters will always be a consideration for all of us. Over the last few years, various individuals or groups have carried out several acts of terrorism which took place in Indonesia, nearly all of which took the lives of the perpetrators as well as innocent people. In general, the Indonesian Ulema Council (MUI) is a wadah (forum) for consultation among Muslim leaders, Ulema, and scholars which plays an important role in providing guidance for the ummah . Apart from these, it also issues fatwas particularly on the things that are linked to theological issues, ${ }^{45}$ as well as terrorism issues where there are certain individuals or groups carrying out acts of violence motivated by theological or doctrinal matters. In order to dispense the duty of providing the fatwa, the MUI uses several methodologies as stipulated in the Decree of the MUI No: U-596/ MUI/XI/1997. ${ }^{46}$

There were two concerns that became the background of Fatwa No 03 Year 2004 of the Indonesian Ulema Council (MUI) concerning terrorism: First, numerous terrorism activities that had been conducted all across the world, even in Indonesia, where there were several bombings which killed many people. It is clear that these activities are very dangerous both to people's lives and the national security, and these activities have also caused financial losses. Second, there is a mistaken perspective among Indonesian muslims in understanding the meaning of jihad as some of them have claimed that jihad is just qital (war) and that bombings are considered to be jihad and amaliyah al-istiyhadiyah that should be

45 Diana Mutia Habibaty, "Peranan Fatwa Dewan Syariah Nasional Majelis Ulama Indonesia Terhadap Hukum Positif Indonesia," Indonesian Journal of Legislation, vol. 14, no. 4 (2017), 448.

46 Rahmat Abd. Rahman, "Metode Ijtihad Komisi Fatwa Majelis Ulama Indonesia," Nukhbatul 'Ulum: Jurnal Bidang Kajian Islam, vol. 2, no. 1 (2016), 2-8. 
performed, even if it meant putting their economies and their lives and the lives of others at risk. ${ }^{47}$

Based on these two factors, it is hoped that perhaps the presence of religious institutions, like the Indonesian Ulema Council (MUI), will be more significant to assist in certain aspects especially in helping the country in fighting terrorism. The initiative to drive in that direction seems visible where the MUI issued the Fatwa regarding terrorism namely the MUI Fatwa No. 3 Year 2004 on terrorism. This fatwa is meant to address the paradigm earlier, given that terrorism is an ideology that has no place in any religion as all religions including Islam forbid any form of violence targeted against others without any valid reasons. ${ }^{48}$ Thereby, the MUI fatwa on terrorism is supposed to be a source of reference for Indonesia. ${ }^{49}$ The subject of the MUI fatwa was divided into three discussions using several masadhir al-ahkam based on the Decree of the MUI No: U-596/MUI/XI/1997 such as using the argumentation based on al-Qur'an, hadith and also qa'idah fiqhiyyah. ${ }^{50}$

\section{SUICIDE BOMBING ACCORDING TO INDONESIAN ISLAMIC SCHOLARS' PERSPECTIVES}

Based on the research reviews of interviews with respondents, it is found that two perspectives are given by respondents regarding suicide bombing, whether it is allowed or prohibited. Essentially all respondents gave similar views on the first perspective, that

47 Iwan Suherman, "Tinjauan Hukum Islam Terhadap Aksi Terorisme di Indonesia: Analisis Fatwa MUI No. 03 Tahun 2004 Tentang Terorisme,' (Latihan Ilmiah, Universitas Islam Negeri Syarif Hidayatullah, Jakarta, 2008), 93-96. Lihat juga Sya'dan Zamzani, "Analisis Fatwa MUI Nomor 3 Tahun 2004 Tentang Terorisme" (Latihan Ilmiah, Universitas Islam Negeri Walisongo, Semarang, 2013).

48 Muhammad Faiz, "Fatwa Haram Terorisme: Menelisik Urgensi Fatwa MUI Tentang Terorisme" (Kertas kerja, Islamic Conference on MUI Studies, Hotel Margo, Depok, dalam rangka milad MUI ke42, 26-28 Julai 2017), 4-5.

49 http://mui.or.id/wp-content/uploads/files/fatwa/10.-Terorisme.pdf, accessed on 14 December 2019.

50 http://mui.or.id/wp-content/uploads/files/fatwa/10.-Terorisme.pdf, accessed on 24 January 2020. 
suicide bombing is prohibited by all religious teachings, including Islam, whether in peaceful situations, sulh, or other conditions. This particular perspective is stated by several respondents:

"Suicide bombing is definitely wrong, prohibited, in any dalil, on any reason" (Muhammad Da'i, ViceChancellor I UMS dan Chairman of ICMI Solo)

"I definitely think it is wrong under any reason, and it is clearly prohibited to commit suicide". (Syamsul Bahri, Chairman of DPD LDII Kota Surakarta)

"Suicide bombing is different from amaliyah istisyhadiyah, with suicide bombing, "suicide" is haram, so suicide bombing cannot be categorized as istisyhadi or jihad." (Mu'inudinillah Basri, Chairman DSKS)

Furthermore, there is another perspective where some respondents stated that suicide bombing could be justified in a dharuri condition, where there is no other way but to do a suicide bombing. This perspective is stated by several respondents as:

"Depends on the circumstances and condition, if we are in a sulh or peaceful condition, then there is no law that can justify istisyhad or suicide bombing as permissible acts. It is different when in a truly dharuri condition" (Azhar Nurachman, Chairman of Department Dakwah \& Candidate of DPD WI)

"Depends on the situation. but if we are in a war, and we are threatened and would be attacked, and there is no way to defend yourself and other Muslims, then I think it is permitted to do it to hamper the enemy, in the Prophet era there were (people) who sacrificed themselves and (their bodies) were disposed into the fort (committed) for the benefit (of the people)" (Sirajuddin, Chairman DPD of Wahdah Islamiyah (WI) Surakarta) 
Suicide bombing is often associated with the term "amaliyah al-istisyhadiyah', an activity to achieve syahid death. ${ }^{51}$ However, in the discussion on suicide bombing, there are two main perspectives. First, for those who think suicide bombing as suicide and not 'amaliyah al-istisyhadiyah', the implication is the law of syahid death is not implemented, but the perpetrator is viewed as people who will be thrown in hell because he killed himself and other people. Second, for those who think suicide bombing as syahid death ('amaliyah al-istisyhadiyah), the implication for terrorists is the law of syahid death is implemented for them; therefore they think that in the afterlife they will enter the heaven. ${ }^{52}$

Regardless of the descriptions, based on the two perspectives of the respondents above, suicide bombing is viewed as an act that cannot be justified by Islamic law under any reason or condition. A suicide bombing that results in the death of the perpetrator and cost many innocent lives cannot be categorized as a form of jihad or amaliyah al-istisyhadiyah. The al-Qur'an and hadith have clearly stated that it is haram. His revelation:

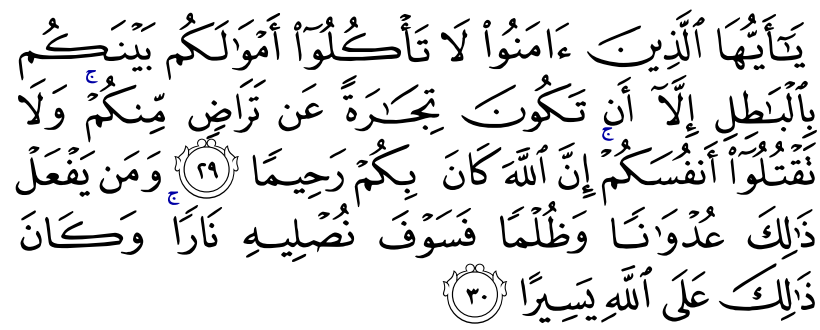

"O you who have believed, do not consume one another's wealth unjustly but only [in lawful] business by mutual consent. And do not kill yourselves [or one another]. Indeed, Allah is to you ever Merciful. And whoever does that in aggression and injustice - then We will drive him into a Fire. And that, for Allah, is [always] easy."

51 Abdul Munip, "Buku Jihad Terjemahan dari Bahasa Arab dan Potensi Radikalisme Beragama di Lembaga Pendidikan," Cendekia: Jurnal Kependidikan dan Kemasyarakatan, vol. 15, no. 2 (2017), 191.

52 Ahmad Thobroni, "Bom Bunuh Diri dan Euthanasia dalam Tinjauan Hukum Islam," Ulul Albab: Jurnal Studi dan Penelitian Hukum Islam, vol. 1, no. 1 (2017), 135. 
(Surah al-Nisā', 4: 29-30)

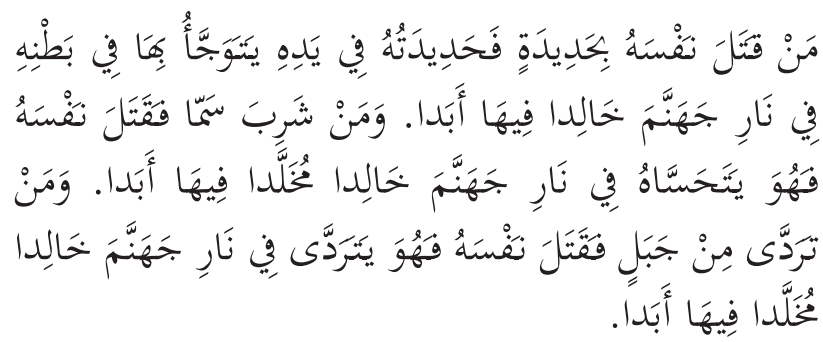

"He who killed himself with steel (weapon) would be the eternal denizen of the Fire of Hell and he would have that weapon in his hand and would be thrusting that in his stomach for ever and ever, he who drank poison and killed himself would sip that in the Fire of Hell where he is doomed for ever and ever; and he who killed himself by falling from (the top of) a mountain would constantly fall in the Fire of Hell and would live there for ever and ever." ${ }_{53}$

\section{PERSPECTIVES OF INDONESIAN ISLAMIC SCHOLARS REGARDING THE MUI FATWA ON TERRORISM}

The threat of terrorist attacks in Indonesia is still not over according to the National Anti-Terrorism Agency (BNPT). ${ }^{54}$ In this context it is hoped that the presence of religious institutions like the Indonesian Council for Ulema (MUI) would be more relevant in providing solutions to the people so that they can live in peace amidst the fight against terror. In fact, as mentioned earlier the MUI had issued Fatwa no. 03 Year 2004 regarding terrorism issues, and by that, the MUI had made clarifications on terrorism, jihad, suicide bombing, amaliyah istishhadiyah and so on. ${ }^{55}$

Unfortunately, the fatwa by MUI regarding terrorism issues, has not been able to start a massive movement in fighting terrorism

\footnotetext{
53 Muslim, Abī al-Ḥsayn Muslim Ibn al-Hajjāj Ibn al-Qushayrī alNaysabūrī, Șaḥ̄ḥ Muslim, 74, "Kitāb al-Īmān," no. hadis 109.

54 https://www.antaranews.com/berita/640885/bnpt-ancamanterorisme-tak-pernah-surut (Accessed: 25 Maret 2019, $17.31 \mathrm{pm}$ ).

55 http://mui.or.id/wp-content/uploads/files/fatwa/10.-terorisme.pdf.
} 
in Indonesia for the reason that MUI fatwa does not bind them. For instance, every year, there are various religiously motivated terrorism incidents in Indonesia, and the irony is those terrorists still thought that their actions were part of jihad. Sad to say, the fatwa by MUI regarding terrorism issues has not been able to set off a massive movement or provide a solution for Indonesia in the fight against terrorism. Over the years, several terrorist attacks had happened in Indonesia and the terrorists made justifications based on religious beliefs that their actions were part of jihad..$^{56}$

\section{Number of Terrorist Attacks According to Years}

\section{Figure 1: The Number of Terrorist Attacks According} to Years

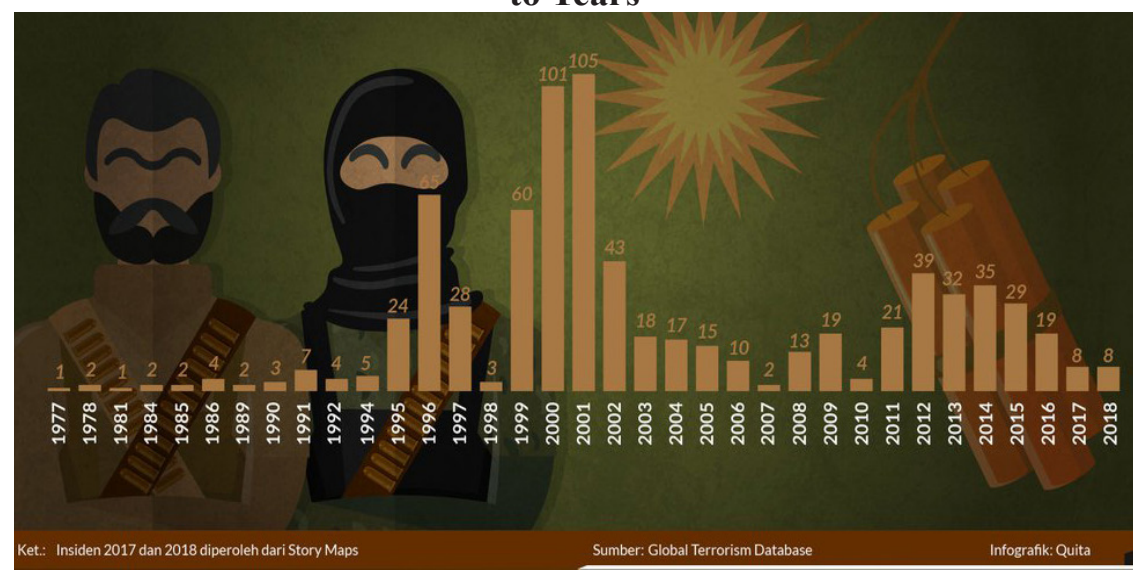

Source: Website from Tirto.id, published on 22 May 2018, https:// tirto.id/terorisme-indonesia-dari-separatisme-hingga-teror-atasnama-agama-cKUK)

56 Abdul Aziz, "Fatwa Haram Terorisme yang Tak Mempan Meredam Aksi Teroris," https://tirto.id/fatwa-haram-terorisme-yang-takmempan-meredam-aksi-teroris-ccnX, accessed on 14 July 2019. 


\section{Figure 2: 8 Clusters of Attackers with Most Attacks} within 1977 to 2018

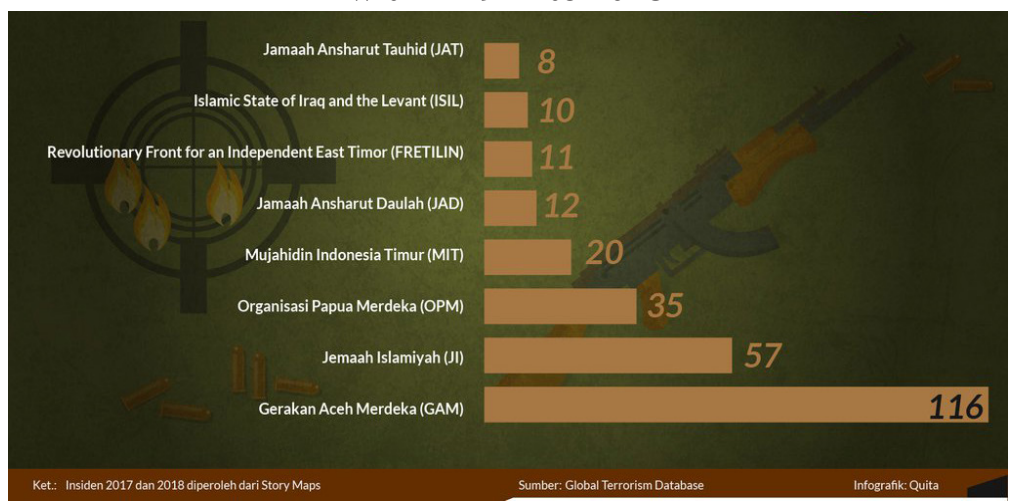

Source : website from Tirto.id, published on 22 May 2018 (https:// tirto.id/terorisme-indonesia-dari-separatisme-hingga-teror-atasnama-agama-cKUK)

The Figure 1 showed the number of terror Indonesia were increased within 1977 till 2001 whereas in 2002 till 2007 it is shown that there was a reduction in terrorism incidents which there were 43 incidents in 2002 and just 2 incidents in 2007. Sadly, the acts of terrorism have been on the increase from 2008 to 2018. The figure 2 described that there are 8 clusters of attackers with most attacks within 1977-2018. For instance, Free Aceh Movement (GAM) was the first cluster with the most attacks with 116 terror attacks while Jemaah Islamiyah (JI) was the second cluster with the most attacks after GAM with 57 terror attacks as well as the another cluster. Nonetheless, the two images above demonstrate that certain terrorist acts that happened in Indonesia were not only driven by theological beliefs but also driven by political issues. ${ }^{57}$

57 Irma Garnesia, "Terorisme Indonesia: Dari Separatisme hingga Teror atas Nama Agama," https://irto.id/terorisme-indonesia-dariseparatisme-hingga-teror-atas-nama-agama-cKUK, accessed on 14 December 2019. 
The Viewpoints of Indonesian Islamic Scholars on the Fatwa Concerning Terrorism Issued by the Indonesian Ulema Council (MUI): An Analysis

Figure 3: The Number of Terrorist Incidents in the Name of Religion According to Terrorist Targets within 1977 to 2018

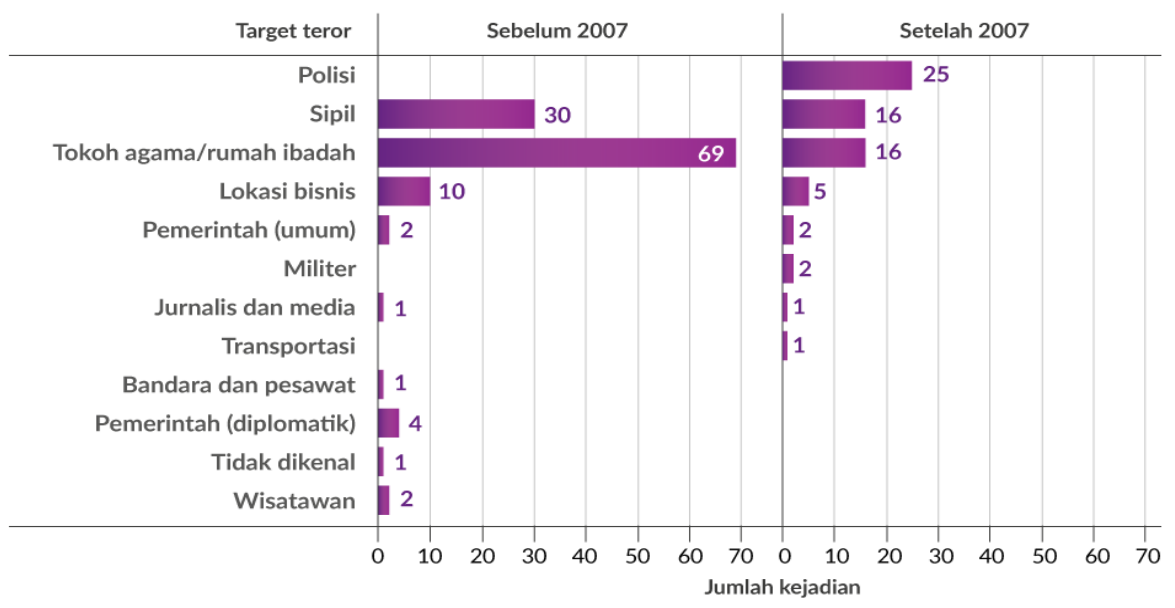

Source: Website from beritagar.id, published on 14 May 2018, (https://beritagar.id/artikel/berita/lain-paham-beda-sasarandalam-teror-di-indonesia)

Figure 4: The Number of Deaths due to Terrorism Attacks in Indonesia within 1977 to 2018

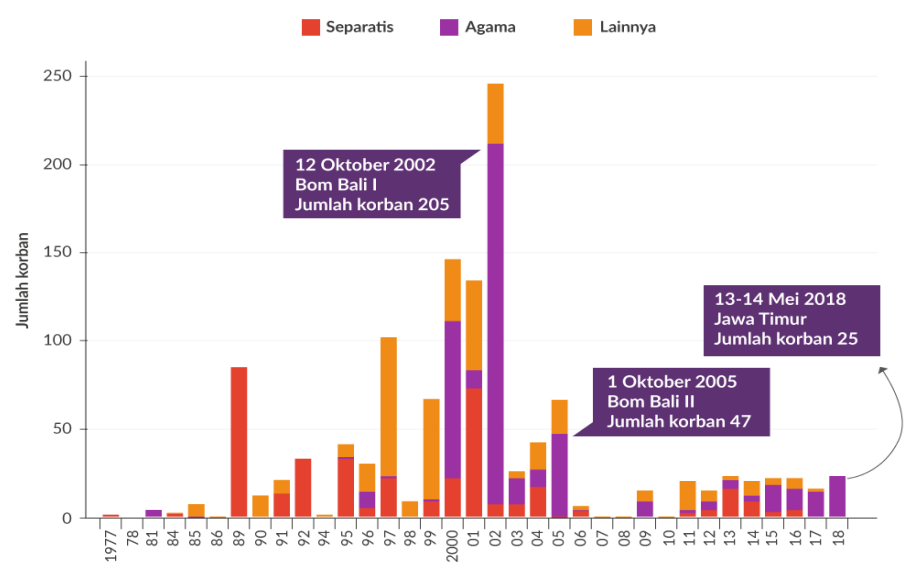

Source: website from beritagar.id, published on 14 May 2018, (https://beritagar.id/artikel/berita/lain-paham-beda-sasarandalam-teror-di-indonesia) 
The Figure 3 showed the number of terrorist incidents in the name of religion according to terrorist targets within 1977 to 2018 either to the polices, civilians, religious figures, house of worship and others. The Figure 4 displayed the number of deaths due to terrorism attacks in Indonesia within 1977 to 2018. Based on the Global Terrorism Database (GTD) said before 2000, the number of terrorist victims was more due to separatist conflict.

But since 2000, the trend has changed where Jemaah Islamiah (JI) began to lunch the terrorist acts which almost all victims of terrorist acts due to bomb attacks. Before 2000, the death rate due to terror in the name of religion was only 16 , but started jumping significantly nearly 23 times just after Bali bomb attacks. Likewise, from the two recent images above, it is highlights that there were 751 terrorist attacks across Indonesia between 1977 to 2018, from which one quarter were terrorist activities based on religious sentiments. ${ }^{58}$

There are two sides to religion which contradict one another. The religion is a medium to find peace, gain clarity, contentment, mindfulness in life, and faith and happiness. However, in this matter religion is frequently being associated with violence for instance, religious conflicts that happened in some countries. There is no religion on earth that uphold acts of terrorism, specially Islam which is totally against it. ${ }^{59}$

After all, Indonesia has an instrument which can respond to any problems linked to religious issues, such as the fatwa released by MUI on terrorism. Even so, this fatwa is still not a long-term solution for Indonesia to prevent any terrorist attacks driven or motivated by theological issues. ${ }^{60}$ How can that be? The fact seems to be that the fatwa remains seriously lacking of socialization efforts by the MUI either to the public or religious institutions. Several interviewees spoke in support of this:

58 Aghnia Adzkia, "Lain Paham Beda Sasaran dalam Teror di Indonesia," https://beritagar.id/artikel/berita/lain-paham-beda-sasar an-dalam-teror-di-indonesia, accessed on 14 December 2019.

59 Fathuddin, "Kebebasan Beragama dalam Bingkai Otoritas Negara," Indonesia Journal of Legislation, vol. 12, no. 2 (2015), 3.

60 https:/tirto.id/fatwa-haram-terorisme-yang-tak-mempan-meredamaksi-teroris-cenX, accessed on 14 July 2019. 
"The truth is this fatwa is still very weak in influencing jamaah, jamaah prefers to listen to their ustad than MUI fatwa, except if the fatwa has been accepted by asatid. There are even some fatwas whose existence are not known by Muslims (Sirajuddin, Chairman of DPD Wahdah Islamiyah Surakarta)

"...To me, it is not quite effective because of a lack of communication. If it is spread intensely (it might be effective) but it is not covered by the media. Maybe (MUI) has put some efforts, but its exposure is not enough. Therefore it is not effective in several regions... MUI should approach all organizations, presenting (the fatwa) and explaining every detail to jama'ah or organizations in several regions, saying "This is the fatwa of MUI on terrorism..." (Azhar Nurachman, Chairman of Department Dakwah \& Candidate of DPD WI)

"...I can only comprehend what fatwa is in the normative sense. There is no problem (with this fatwa). However, it is not being guarded/followed. This erases its substance, thus making it completely not effective. This is because MUI has not been given the opportunity to control and socialize it in education (institutions) or community..." (Shobbarin Syakur, Secretary-General of Majelis Mujahidin Indonesia)

"MUI's fatwa are extraordinary. In preventing terrorism and radicalism, it is a good measure, and it should be (circulated) to religious groups, these groups will pass it to their ummah, ummah to the community and it should be integrated. In order for this fatwa to be really effective, there must be a follow-up, which is combining the strength of all instruments to support (this fatwa), so that (this fatwa) will be understood on the lowest level and widely implemented among the people..." (Syamsul Bahri,

\section{Chairman of DPD LDII Surakarta)}


"I think this fatwa is really good because its content is based on hujjah of the Quran and hadith as well as fiqh, now it's a matter on how to implement it, especially on the lowest level. Therefore ummah can perform the fatwa... all this time MUI fatwa has a weak effect on the people, and if it is delivered by khatib it won't be forwarded... So, there should be direct communication, and the government officials rarely read these fatwas, some read them, but do not understand their urgency and their need to be circulated" (KH. Muhammad Dian Nafi, Caretaker of Pesantren AlMuayyad Windan Surakarta)

"...our instuition is MUI, it shouldn't be only in theory, but it should be understood "MUI has a fatwa concerning this (topic)", this is the first time I knew about this fatwa (terrorism)..." (Ahmad Sukidi, Chairman of Majelis Pendidikan Kader Pimpinan Daerah Muhammadiyah Surakarta)

“...the most important thing about fatwa after its formulation is how to socialize it, it needs to be socialized... if it's socialized and the (dignity) of MUI is still strong then (the fatwa) will have strong influence... the way I see it, its socialization has not run well and sometimes it can be tendentious" (Mu'inudinillah Basri, Chairman of DSKS)

Socialization is being used by sociologists, social psychologists, anthropologists, politicians and educationalists to describe and spread information, values, behaviors and ideologies that provide a person with both the skills and habits required in engaging with their own community. Socialization is thus "the means by which social and cultural continuity are attained" ${ }^{61}$ Any information that is transmitted and socialized either by an organization, institution, governmental agencies or individual is intended to provide

${ }_{61}$ Ridho Falah Adli, "Strategi Komunikasi Majelis Ulama Indonesia dalam Mensosialisasikan Fatwa Sesat Ormas Gafatar," (Latihan Ilmiah, Sarjana Muda, Universitas Islam Negeri Syarif Hidayatullah, Jakarta, 2016), 30. 
information towards its socialization target in conjunction with clear objectives. $^{62}$

In conclusion, based on the analysis findings, it is found that the lack in efforts to socialize MUI fatwas contributed to the indifference of society towards the implementation of these fatwas, causing them to be less efficient. On the other hand, public socialization regarding MUI fatwas including fatwas concerning terrorism is indeed a key component of the internalization of religious beliefs among Muslim people.

\section{CONCLUSION}

The MUI Fatwa regarding the terrorism has yet to be the best solution to handle terrorism issues in Indonesia due to a lack of or poor sosialization of the fatwa. So, the MUI fatwa regarding terrorism should be distributed or spread further by print or electronic media in order to reach the people living in different regions where a government-supported discourse is needed. The practice of socialization can be implemented through socialization activities including promoting silaturrahim which simply means the strengthening of relationships with relatives and the brotherhood, religious organizations, majelis ta'lim, mosques and madrasa caretakers and many other parties where the ulema are the biggest and most powerful shareholder in those communities.

This could be accomplished through the use of varying media instruments, like the television. The television is amongst the most convenient and effective broadcast media in order to spread information or knowledge. In order to implement this fatwa, it is recommended that the Indonesian Ulema Council (MUI) socialize their fatwa using several approaches, and doing so repeatedly so as to transmit the message of the fatwa and its substance to the society. Messages of the fatwa will reach the people especially if it comes from an organization like MUI. Educational approaches

62 Syarifah Zahrina Firda, "Strategi Komunikasi MUI dalam Mensosialisasikan Fatwa Pedoman Bermuamalah di Media Sosial," (Latihan Ilmiah, Sarjana Muda, Universitas Islam Negeri Hidayatullah Jakarta, 2018), 34-35. 
and broadcast media can also be used by MUI to socialize their fatwas.

\section{REFERENCES}

'Abd al-Karīm Zaydān, al-Wajīz fì Sharh al-Qawā 'id al-Fiqhiyyah fì al-Sharī'ah al-Islāmiyyah (Bayrūt: Mu'assah al-Risālah, 2001).

'Abd Allāh bin Muḥammad bin Sa'ad, al-Fatwā fí al-Sharī'ah alIslāmiyah (Riyāḍ: Maktabah Obeikan, 2008).

Abdul Aziz, "Fatwa Haram Terorisme yang Tak Mempan Meredam Aksi Teroris," https://tirto.id/fatwa-haram-terorisme-yangtak-mempan-meredam-aksi-teroris-ccnX, accessed on 14 July 2019.

Abdul Muis Naharong, "Terorisme Atas Nama Agama," Journal of Refleksi, vol. 13, no. 5 (2013), 593-622.

Abdul Munip, "Buku Jihad Terjemahan dari Bahasa Arab dan Potensi Radikalisme Beragama di Lembaga Pendidikan," Cendekia: Jurnal Kependidikan dan Kemasyarakatan, vol. 15, no. 2 (2017), 175- 196.

Abī Dāwud, Sulayman Ibn al-Ash'ath al-Sijistānī al-'Azdī, Sunan $A b \bar{\imath} D \bar{a} w \bar{u} d$, vol. 5, ed. 'Abd al-Lațîf Hirz Allāh (Dimashq: Dār al-Risālah al-'Alamiyyah, 2009).

Abu Rokhmad, "Radikalisme Islam dan Upaya Deradikalisasi Paham Radikal," Walisongo: Jurnal Penelitian Sosial Keagamaan, vol. 20, no. 1 (2012), 179-113.

Aghnia Adzkia, "Lain Paham Beda Sasaran dalam Teror di Indonesia," https://beritagar.id/artikel/berita/lain-pahambeda-sasaran-dalam-teror-di-indonesia, accessed on 14 December 2019.

Aḥmad bin Ḥamdan al-Ḥarranī al-Ḥanbalī, Sifāt al-Fatwā wa al-Muftī wa al-Mustaftī (Dimashq: al-Maktabah al-Islāmī, $1380 \mathrm{H})$.

Ahmad Mukhlishin, Aan Suhendri, Muhammad Dimyati, "Metode Penetapan Hukum dalam Berfatwa," Al-Istinbath: Jurnal Hukum Islam, vol. 3, no. 2 (2018), 168-169. 
Ahmad Rais Karnawan, "Latar Belakang Terorisme dilihat dari Perspektif Sosio-Historis," https://www.academia. edu/38460413/latar_belakang_terorisme_dilihat_dari perspektif_sosio-historis., accessed on 22 October 2019.

Ahmad Thobroni, "Bom Bunuh Diri dan Euthanasia dalam Tinjauan Hukum Islam," Ulul Albab: Jurnal Studi dan Penelitian Hukum Islam, vol. 1, no. 1 (2017), 134-151.

August Corneles Tamawiy, "Bom Surabaya 2018: Terorisme dan Kekerasan Atas Nama Agama," Gema Teologika: Jurnal Teologi Kontekstual \& Filsafat Keilahian, vol. 4, no. 2 (2019), 175-194.

Chaider S. Bamualim \& Ridwan al-Makassary, "Nexus Antara Fundamentalisme Islam dan Terorisme," Millah: Jurnal Studi Agama, vol. 5, no.1 (2006), 36.

Departemen Pendidikan Nasional, Kamus Bahasa Indonesia (Jakarta: Pusat Bahasa, 2008).

Diana Mutia Habibaty, "Peranan Fatwa Dewan Syariah Nasional Majelis Ulama Indonesia Terhadap Hukum Positif Indonesia," Indonesian Journal of Legislation, vol. 14, no. 4 (2017), 447-454.

Fathuddin, "Kebebasan Beragama dalam Bingkai Otoritas Negara," Indonesia Journal of Legislation, vol. 12, no. 2 (2015), 1-25.

Fatkhuri, Faktor Pendukung Terbentuknya Radikalisme dan Terorisme di Indonesia (Jakarta: Universitas Pembangunan Nasional Veteran, 2012).

Golda Eska, "Terorisme Ancaman Nyata yang Memengaruhi Keutuhan Bangsa," https://mediaindonesia.com/ $\mathrm{read} /$ detail/211901-terorisme-ancaman-nyata-yangmemengaruhi-keutuhan-bangsa, accessed on 25 March 2019.

Heri Fadli Wahyudi \& Fajar, "Metode Ijtihad Komisi Fatwa Majelis Ulama Indonesia dan Aplikasinya dalam Fatwa," Cakrawala: Jurnal Studi Islam, vol. 13, no. 2 (2018), 120133. 
http://mui.or.id/wp-content/uploads/files/fatwa/10.-Terorisme. pdf, accessed on 14 December 2019.

http://mui.or.id/wp-content/uploads/files/fatwa/10.-Terorisme. pdf, accessed on 24 January 2020.

http://mui.or.id/wp-content/uploads/files/fatwa/10.-terorisme.pdf, accessed on 24 January 2020.

https://tirto.id/fatwa-haram-terorisme-yang-tak-mempanmeredam-aksi-teroris-ccnX, accessed on 14 July 2019.

https://www.antaranews.com/berita/640885/bnpt-ancamanterorisme-tak-pernah-surut, accessed on 25 March 2019.

https://www.jawapos.com/jpg-today/10/09/2018/rawan-pahamradikal-solo-masuk-zona-merah-terorisme/, accessed on 22 April 2019.

https://www.radarcirebon.com/3-hal-biang-keladi-terorisme-inikata-bin.html, accessed on 25 March 2019.

Irma Garnesia, "Terorisme Indonesia: Dari Separatisme hingga Teror atas Nama Agama," https://tirto.id/terorismeindonesia-dari-separatisme-hingga-teror-atas-nama-agamacKUK, accessed on 14 December 2019.

Isa Ansori, "Kedudukan Fatwa di Beberapa Negara Muslim (Malaysia, Brunei Darussalam dan Mesir)," Analisis: Jurnal Studi Keislaman, vol. 17, no. 1 (2017), 138-139.

Iwan Suherman, "Tinjauan Hukum Islam Terhadap Aksi Terorisme di Indonesia: Analisis Fatwa MUI No. 03 Tahun 2004 Tentang Terorisme,' (Latihan Ilmiah, Universitas Islam Negeri Syarif Hidayatullah, Jakarta, 2008).

Junaidi Abdillah, "Radikalisme Agama: Dekontruksi Tafsir AyatAyat Kekerasan dalam Al-Quran," Journal: Kalam, vol. 8, no. 2 (2014), 281-300.

Kementerian Wakaf Kuwait, al-Mawsū'ah al-Fiqhiyyah alKuwaytiyyah, vol. 32 (Mișr: Mathabi' Dār al-Șafwah, 1988).

KH. Ma'ruf Amin, Pengantar dalam Himpunan Fatwa MUI 2003 (Jakarta: MUI Pusat, 2003). 
M. Erfan Riadi, "Kedudukan Fatwa ditinjau dari Hukum Islam dan Hukum Positif: Analisis Yuridis Normatif," Ulumuddin: Journal of Islamic Legal Studies, vol. 6, no. 4 (2010), 471 472.

Michael Seno Rahardanto, "Mengkaji Sejumlah Kemungkinan Penyebab Tindak Terorisme: Kajian Sosio-Klinis," Experientia: Jurnal Psikologi Indonesia, vol. 1, no. 1 (2012), 70-78.

Mohd Anuar Ramli \& Rahimin Affandi Abdul Rahim, "Fatwa Sebagai Medium Counter-Terrorisme: Rethinking Eksistensi Fatwa dalam Menangani Terorisme," Al-Banjari: Jurnal Ilmiah Ilmu-Ilmu Keislaman, vol. 17, no. 2 (2018), 223-225.

Muhammad Faiz, "Fatwa Haram Terorisme: Menelisik Urgensi Fatwa MUI Tentang Terorisme" (Kertas kerja, Islamic Conference on MUI Studies, Hotel Margo, Depok, dalam rangka milad MUI ke-42, 26-28 Julai 2017).

Muḥammad Jalāl al-Dīn al-Qāșimī, al-Fatwā fì al-Islām, ed. Muḥammad 'Abd al-Ḥakīm al-Qāḍī (Bayrūt: Dār al-Kutub al-'Ilmiyyah, 1986).

Muḥammad Șidqī Ibn Aḥmad, al-Wajīz fì Sharh al-Qawā'id alFiqhiyyah al-Kulliyyah (Bayrūt: Mu'assasah al-Risālah, 1996).

Muhd Imran Abd Razak \& Rahimin Affandi Abdul Rahim, "Analisis Fahaman Ekstremis Agama dan Media Sosial di Malaysia," Asian Journal of Environment, History and Heritage, vol. 2, no. 1 (2018), 91-103.

Muslim, Abī al-Husayn Muslim Ibn al-Hajjāj Ibn al-Qushayrī alNaysabūrī, Șahīh Muslim (Bayrūt: Dār al-Fikr, 2003).

Muslim, Ab̄̄ al-Ḥusayn Muslim Ibn al-Ḥajjāj Ibn al-Qushayrī al-Naysabūrī, Sahīh Muslim (Mamlakah al-'Arabiyah alSu'ūdiyyah: Dār al-Salām, 2000).

Al-Nawawī, Abī Zakariyyā Maḥy al-Dīn Ibn Sharf, al-Majmū ‘ Sharh al-Muhadhdhab, vol. 1 (Jeddah: Maktabah al-Irshād, 1999). 
Rahmat Abd. Rahman, "Metode Ijtihad Komisi Fatwa Majelis Ulama Indonesia," Nukhbatul 'Ulum: Jurnal Bidang Kajian Islam, vol. 2, no. 1 (2016), 2-8.

Ridho Falah Adli, "Strategi Komunikasi Majelis Ulama Indonesia dalam Mensosialisasikan Fatwa Sesat Ormas Gafatar," (Latihan Ilmiah, Sarjana Muda, Universitas Islam Negeri Syarif Hidayatullah, Jakarta, 2016).

Rusli, "Tipologi Fatwa di Era Modern dari Offline ke Online," Hunafa: Jurnal Studia Islamika, vol. 8, no. 2 (2011), 296306.

Slamet Suhartono, "Eksistensi Fatwa Majelis Ulama Indonesia dalam Perspektif Negara Hukum Pancasila," Al-Ihkam: Jurnal Hukum dan Pranata Sosial, vol. 12, no. 2 (2017), 449-450.

Sya'dan Zamzani, "Analisis Fatwa MUI Nomor 3 Tahun 2004 Tentang Terorisme" (Latihan Ilmiah, Universitas Islam Negeri Walisongo, Semarang, 2013).

Syarifah Zahrina Firda, "Strategi Komunikasi MUI dalam Mensosialisasikan Fatwa Pedoman Bermuamalah di Media Sosial," (Latihan Ilmiah, Sarjana Muda, Universitas Islam Negeri Hidayatullah Jakarta, 2018).

Tiara Firdaus Jafar, Arfin Sudirman \& Affabile Rifawan, "Ketahanan Nasional Menghadapi Ancaman Lone Wolf Terrorism di Jawa Barat," Journal Ketahanan Nasional, vol. 25, no. 1 (2019), 81-82.

Usman, "Model Diradikalisasi Narapidana Terorisme Studi Perbandingan Diradikalasi di Yaman, Arab Saudi, Singapura, Mesir dan Indonesia," Inovatif: Jurnal Ilmu Hukum, vol. 7, no. 2 (2014), 1-16.

Yusril Ihza Mahendra, "Hukum Islam Adalah The Living Law", Republika.co.id, https://www.republika.co.id/berita/ nasional/hukum/16/12/24/oiope6301-yusril-hukum-islamadalah-the-living-law, accessed on 12 December 2019.

Yūsuf al-Qaraḍāwī, al-Fatwā bayna al-Indibāt wa al-Tasayyub (Qāhirah: Dār al-Șahwah li al-Nashr, 1988). 
The Viewpoints of Indonesian Islamic Scholars on the Fatwa Concerning Terrorism Issued by the Indonesian Ulema Council (MUI): An Analysis

Zulfi Mubarak, "Fenomena Terorisme di Indonesia: Kajian Aspek Teologi, Ideologi dan Gerakan," Salam: Jurnal Studi Masyarakat Islam, vol. 15, no. 2 (2012), 240-254.

Zulkifli Mohamad, "Institusi Mufti dan Fatwa: Satu Analisa Terhadap Enakmen dan Beberapa Fatwa Pilihan Negeri Sembilan," (Ph.D Thesis, Universiti Sains Malaysia, Pulau Pinang, 2004). 
Jurnal Fiqh, Vol. 17 No. 1 (2020) 171-204 